\title{
ROLE OF UNCERTAINTY IN DEBT-GROWTH NEXUS*
}

\section{Mindaugas Butkus $^{a}$ (iD), Diana Cibulskiene ${ }^{a}$ (D) Lina Garsviene ${ }^{a}$ (D), Janina Seputiene ${ }^{a}$}

\begin{abstract}
This paper analyses uncertainty as one of the factors that affect the public debt-growth nexus. We put forward a hypothesis that uncertainty mediates the effect of public debt on economic growth. The empirical examination of the mediating effect is based on the neoclassical growth equation and consistent with specifications previously used to analyse the sources of heterogeneity in the debt-growth relationship. Since one part of the uncertainty is financial risk, which is closely related to the financial sector stability, we use interest rate spread as a main variable, and the risk premium on lending as an alternative one to proxy financial risk and thus, to some extent, uncertainty. Our results show that lower uncertainty is related to a bigger positive effect of debt on growth and a higher turning point in the debt-growth nexus. On the contrary, higher uncertainty leads to a lower positive and more considerable negative effect of debt on growth in both linear and quadratic specifications.
\end{abstract}

Keywords: Debt-growth nexus, uncertainty, interest rate spread, risk premium, financial risk JEL Classification: E43, H63, H68, O40

\section{Introduction}

Since the seminal paper of Reinhart and Rogoff (2010), the non-linear debt-growth relationship has been widely researched in the literature aiming to estimate a debt-to-GDP threshold at which the marginal impact of debt changes from positive to negative. Reviews of studies (see Rahman et al., 2019; Koroglu, 2019; Bentour, 2020; Salmon and de Rugy, 2020) clearly show no single debt threshold that is common to all countries. Therefore, a growing body of research aims to identify the factors on which the debt threshold is

* This paper is made as an output of the research project funded by the Research Council of Lithuania, grant number S-MIP-19-65.

a Vilnius University Siauliai Academy, Siauliai, Lithuania

E-mails: mindaugas.butkus@sa.vu.lt, diana.cibulskiene@sa.vu.lt, lina.garsviene@sa.vu.lt, janina. seputiene@sa.vu.1t 
dependent. The literature points to saving, investment and interest rates as the main channels through which the negative effect of public debt on economic growth originates, and increasing uncertainty certainly plays a role. Ricardo's equivalence theory assumes that as debt increases, higher government revenues will be needed in the future to repay the debt, resulting in higher taxes. This raises uncertainty about taxes in the future and may potentially impact on incentives to save and invest.

The relationship between debt and uncertainty can be grounded on two arguments. Firstly, high debt can cause expectations about a rise in taxes and may therefore reduce investments. No matter if there are no effects on interest rates or interest rate spread, investments may decline. Pattillo et al. (2011) point to the expectations that higher debt will lead to a higher tax burden on capital. The economy can suffer from debt overhang, i.e., that a certain level of debt creates disincentives to invest as investors may start to expect their profits to be taxed to service the debt. According to Munir and Mehmood (2018), a high public debt level may signal higher uncertainty about countries' economic conditions and discourage foreign investments. Anzuini et al. (2020) discuss the effects arising from fiscal policy uncertainty and find that the outcomes of the same change in the government budget depend on fiscal policy uncertainty. Expansionary fiscal policy leads to Keynesian effects if its implementation reduces (or at least does not increase) uncertainty.

Secondly, high public debt levels may serve as a signal of higher uncertainty about countries' economic conditions, increase the country's default risk, which might lead to a decrease in national savings and, consequently, to an increase in interest rates, less investment, higher risk premium and inflation rate (Greiner, 2014; Ahlborn and Schweickert, 2016; Gomez-Puig and Sosvilla-Rivero, 2017). Higher debt can lead to higher borrowing costs and higher interest rate spread, which shows the debt effect on the financial sector stability (Al Shubiri and Jamil, 2017).

In this paper, we aim to assess whether debt in conjunction with uncertainty has an impact on economic growth, putting forward a hypothesis that uncertainty mediates the effect of public debt on economic growth.

The risk premium is considered in the literature as an indicator of uncertainty. Alcidi and Gros (2019) state that countries with high debt levels often pay a risk premium. The combination of a high debt level with a high risk premium creates self-reinforcing loops. Low interest rates tempt high-debt countries to accumulate further debt. However, low risk-free rates should not be taken as a justification to increase public debt, which cannot be financed at a risk-free rate. Estimations show that a debt-to-GDP ratio of $130 \%$ constitutes a critical threshold, where the line between sustainability and unsustainability is fragile. With a debt ratio above this 'reference value', a government might struggle 
to cope with the cost of debt. Below this value, however, a positive loop of debt reduction can occur.

Turner and Spinelli (2012) also identify high risk premium as one of the uncertainty factors. It is associated with increased government indebtedness, which has risen substantially in the wake of the crisis for many countries. They conclude that when gross government indebtedness-to-GDP ratio passes a threshold of 75\%, then long-term interest rates increase by 4 basis points for every additional percentage point increase in the government debt-to-GDP ratio. These findings correspond with the conclusions of Egert (2010) and Laubach (2009), who found that the risk premium as a difference between short-term and long-term interest rates appears to be a non-linear function of public debt.

The IMF (2017) and the European Commission (2018) use a simple rule of thumb that the risk premium, defined as the difference between the interest rate on public debt of any particular country and the riskless rate, increases by 3-4 basis points for every percentage point increase in the debt-to-GDP ratio above 60\%. Alcidi and Gros (2019) suggest that the cost of debt will be higher at a higher debt level not only because there is more debt to service but also because the cost of each unit of debt (i.e., the interest rate) will increase. Ferreira and Duarte (2011) emphasise that the correct management of public debt influences a fall in risk premium. Huixin (2012) presents a study on the interactions between sovereign risk premium and fiscal policy under conditions of fiscal limit in developed countries, finding a non-linear relation between sovereign risk premiums and the level of public debt in line with the empirical evidence.

The interest rate spread is also used as an indicator of uncertainty. Tamborini (2013) analysed the interest rate spread and public debt dynamics. His findings show that different speeds, fiscal efforts, reciprocal spillovers and chances of success of governments' convergence plans towards a common debt target depend on the heterogeneity of initial conditions and interdependence of debt dynamics via the interest rate spread. Blanchard (2019) points out that increased government debt leads to more frequent default, which leads to an increase in the interest rate spread. Evans (2020), using Blanchard's calibration strategy, tested whether long-run average welfare effects of increased debt survive realistic increases in risk. He did not find any positive long-run average welfare gains from rising public debt in any of the suggested calibrations. Greenlaw et al. (2013) find evidence of non-linearities in the relationship between borrowing rates on sovereign debt and its proportion to GDP in the economies studied. These authors point out that sovereign interest rates rise much more quickly when debt levels are high. However, Blanchard (2019) discusses some arguments why risks associated with higher debts are manageable: for example, safe interest rates are 
expected to remain below growth rates for a long time, that is the issuance of debt without a later increase in taxes.

However, there is a lack of literature investigating the impacts of public debt on economic growth under different financial sector uncertainty levels. Gomez-Puig and Sosvilla-Rivero (2017) suggest that future research on debt-growth nexus can be supplemented with analysis of uncertainty channels (e.g., sovereign risk premium, expected future tax rates, etc.) that drive the debt-growth relationship. Our paper attempts to fill the gap by exploring whether the impact of public debt on economic growth varies across countries with different degrees of uncertainty, which we proxy by interest rate spread and risk premium.

Lower interest rate spread is related to a better supply of money, leading to economic and efficiency growth (Thalassinos et al., 2013; Fetai, 2015). An increase in interest rate spread will directly affect the non-banking sector and its efficiency. It will lead to higher operating costs and, thus, contribute to reduced lending and investment, and eventually to a fall in economic growth and increasing uncertainty. Interest rate spread plays a key role in the level of investment and savings in the economy. Growing uncertainty adversely affects the health of the financial sector. Reductions in credit availability push the economy into a recession, as businesses and consumers cannot raise funds to invest or spend when funds are needed the most (Baum et al., 2020). Lian et al. (2020) explore the impact of growth forecast errors and changes in the US VIX index (which presents uncertainty in the financial markets' expectations for future investment changes) on interest rates. They show that higher public debt is associated with a more considerable increase in interest rates and interest rate spread in response to adverse economic growth and global volatility shocks. Rogoff (2020) suggests that interest rates and interest rate spread can rise during financial sector instability periods, increasing uncertainty and heightening the tension between fiscal stimuli and future debt sustainability.

\section{Model, Data and Estimation Strategy}

Our model for examining the mediating effect of uncertainty on the debt-growth nexus is based on the neoclassical growth equation and consistent with specifications previously used to analyse the sources of heterogeneity in the debt-growth relationship (Panizza and Presbitero, 2013; Eberhart and Presbitero, 2015, Ahlborn and Schweickert, 2016; Gómez-Puig and Sosvilla-Rivero, 2017; Chiu and Lee, 2017; Law et al., 2021). Assuming that the debt effect on growth remains constant irrespective of debt values (i.e., the debtgrowth relationship is linear), the neoclassical growth equation for the panel data takes the following form: 


$$
\begin{aligned}
& \Delta \ln Y_{i, t \rightarrow t+5}=\alpha+\beta_{1} \ln Y_{i, t}+\beta_{2} G E_{i, t}+\beta_{3} \ln G_{i, t}+\beta_{4} \ln S_{i, t}+\beta_{5} \Delta \ln P O P_{i, t}+\beta_{6} \Delta \ln C P I_{i, t} \\
& +\beta_{7} \ln G C F_{i, t}+\beta_{8} \ln T_{i, t}+\beta_{9} \ln D_{i, t}+\gamma_{i}+\theta_{i}+\varepsilon_{i, t},
\end{aligned}
$$

where $\Delta \ln Y_{i, t \rightarrow t+5}$ stands for the 5-year forward-looking $(t \rightarrow t+5)$ average per capita GDP growth rate in the country $i, Y_{i, t}$ is the per capita GDP at constant prices in the initial period $t, G E_{i, t}$ is the World Bank's (WB) estimate of government effectiveness used to proxy effective governance, $G_{i, t}$ stands for the government size in the economy, $S_{i, t}$ is the secondary school enrolment used to proxy human capital, $\triangle \ln P O P_{i, t}$ is the population growth and $\triangle \ln C P I_{i, t}$ is the change in the consumer price index used to proxy inflation, proxy the capital investment rate and $T_{i, t}$ trade openness, $D_{i, t}$ is the public debt-to-GDP ratio (a more detailed explanation of the variables is provided in Table 1). $\gamma_{i}$ is the term for the time-constant, country-specific effects, $\theta_{i}$ is the term for the time dummies, and $\varepsilon_{i, t}$ is the iid error term. $\alpha$ and $\beta_{(\cdot)}$ are parameters to be estimated. All variables except government effectiveness are logged and thus all estimated parameters, except $\beta_{3}$, are interpreted as coefficients of elasticity.

Three strategies are usually applied in the regression analysis framework to examine the effect of a mediator on the relationship between the factor and the outcome variable. One is related to splitting the sample into two or more groups according to the potential mediator values and comparing the estimated effects of the factor on the outcome. The second strategy involves an interaction term between the factor and the mediator to model the conditional effect in the multiplicative regression setting. The third one is the so-called threshold regression framework. Our general examination is based on the multiplicative regression model approach since it allows more in-depth modelling of the mediating effect. The sample splitting approach will be used for the robustness check of the general estimations.

In this paper, we examine uncertainty as one of the factors that influence the public debt-growth nexus. We use interest rate spread (IRS) and risk premium on lending (RPL) to proxy uncertainty. Interest rate spread, which shows the difference between the commercial bank lending rate and the commercial bank deposit rate, will be used as the primary proxy. The alternative variable, RPL, will be used for the robustness check.

To model the mediating effect of the uncertainty on the linear debt-growth relationship, we can employ the following multiplicative equation:

$$
\Delta \ln Y_{i, t \rightarrow t+5}=\alpha+\ldots+\beta_{9} \ln D_{i, t}+\beta_{10}\left[\ln D_{i, t} \times I R S_{i, t}\right]+\beta_{11} I R S_{i, t}+\gamma_{i}+\theta_{i}+\varepsilon_{i, t}
$$

where $I R S_{i, t}$ is the interest rate spread used to proxy the uncertainty, $\ln D_{i, t} \times I R S_{i, t}$ is the interaction between the debt and the interest rate spread, which allows us to model how the linear debt-growth relationship is affected by uncertainty. The conditional 
slope coefficient of the linear debt-growth relationship, which the IRS mediates, can be calculated as $\beta_{9}+\beta_{10} I R S_{i, t}$ with the conditional standard error equal to $\sqrt{\operatorname{var}\left(\beta_{9}\right)+I R S_{i, t}^{2} \times \operatorname{var}\left(\beta_{10}\right)+2 \times I R S_{i, t} \times \operatorname{cov}\left(\beta_{9}, \beta_{10}\right)}$. Having the estimated conditional coefficient and its conditional standard error, the t-ratio and confidence intervals can be calculated using the usual formulae.

A growing body of research (see Rahman et al., 2019; Koroglu, 2019; Bentour, 2020; Salmon and de Rugy, 2020 for a review of research results) confirms that the debt-growth relationship is not constant and depends on the debt level. The non-linear (more precisely, quadratic) relationship between debt and growth can be expressed by augmenting Equation 1 with the squared debt term and estimating the following specification:

$$
\Delta \ln Y_{i, t \rightarrow t+5}=\alpha+\ldots+\beta_{9} \ln D_{i, t}+\beta_{12}\left(\ln D_{i, t}\right)^{2}+\gamma_{i}+\theta_{i}+\varepsilon_{i, t},
$$

where, assuming that $\beta_{9}>0$ and $\beta_{12}<0$, the turning point in the direction of the relationship between debt and growth, which takes the form of an inverted $\mathrm{U}$, can be calculated as $\exp \left\{-\widehat{\beta_{9}} / 2 \widehat{\beta_{12}}\right\}$.

In the case of the quadratic debt-growth nexus, the moderating effect of the uncertainty on the debt-growth relationship can be examined using the following specification:

$$
\begin{aligned}
& \Delta \ln Y_{i, t \rightarrow t+5}=\alpha+\ldots+\beta_{9} \ln D_{i, t}+\beta_{10}\left[\ln D_{i, t} \times I R S_{i, t}\right]+\beta_{11} I R S_{i, t}+\beta_{12}\left(\ln D_{i, t}\right)^{2} \\
& +\beta_{13}\left[\left(\ln D_{i, t}\right)^{2} \times I R S_{i, t}\right]+\gamma_{i}+\theta_{i}+\varepsilon_{i, t}
\end{aligned}
$$

where the conditional slope coefficient of the debt-growth relationship, which is quadratic and mediated by the interest rate spread, can be calculated as $\beta_{9}+\beta_{10} I R S_{i, t}+\beta_{12} \ln D_{i, t}+\beta_{13}\left[\ln D_{i, t} \times I R S_{i, t}\right]$ with the conditional standard error equal to

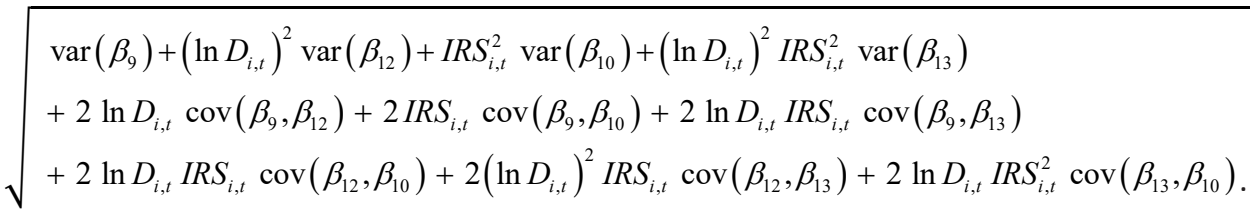

Our unbalanced panel data set covers 104 countries in different geographical regions and income groups over the period 1998-2017. In total, these countries account for around $95 \%$ of the world's GDP and $80 \%$ of the world's population. The total number of growth episodes is equal to 924 and the average per country is 8.88 ( $\min .5$, max. 14). The data 
are collected from two WB databases: World Development Indicators and Worldwide Governance Indicators, and from the OECD World Economic Outlook database. Table 1 presents the data and descriptive statistics.

Table 1: Variables and descriptive statistics

\begin{tabular}{|c|c|c|c|c|c|c|}
\hline Variable & Abbreviation & Mean & Median & S.D. & Min. & Max. \\
\hline $\begin{array}{l}\text { 5-year average per capita GDP } \\
\text { growth rate, } \%\end{array}$ & $\Delta \ln Y_{i, t \rightarrow t+5}$ & 2.4 & 2.4 & 2.5 & -9.1 & 12.0 \\
\hline GDP per capita (constant 2010 USD) & Y & 10.007 & 4.960 & 12.948 & 289 & 75.794 \\
\hline Government effectiveness estimate & GE & 0.03 & -0.09 & 0.83 & -1.77 & 2.12 \\
\hline $\begin{array}{l}\text { General government final con- } \\
\text { sumption expenditure ( } \% \text { of GDP) }\end{array}$ & G & 15.8 & 15.2 & 5.7 & 1.3 & 47.2 \\
\hline $\begin{array}{l}\text { School enrolment, secondary } \\
\text { (\% gross) }\end{array}$ & $S$ & 77.1 & 83.6 & 25.7 & 6.2 & 156.1 \\
\hline Population growth, \% & $\triangle \mathrm{InPOP}$ & 1.4 & 1.3 & 1.6 & -2.6 & 20.0 \\
\hline Inflation (annual change in CPI) \% & $\Delta \operatorname{lnCPI}$ & 6.9 & 5.0 & 7.9 & -3.1 & 198.0 \\
\hline Gross capital formation ( $\%$ of GDP) & GCF & 24.9 & 23.5 & 7.9 & 7.5 & 69.5 \\
\hline $\begin{array}{l}\text { Trade (exports plus imports } \\
\text { of goods and services, \% of GDP) }\end{array}$ & $T$ & 88.9 & 80.8 & 47.4 & 22.1 & 431.3 \\
\hline $\begin{array}{l}\text { General government gross debt } \\
\text { (\% of GDP) }\end{array}$ & $\mathrm{D}$ & 46.5 & 39.2 & 34.4 & 0.5 & 252.4 \\
\hline $\begin{array}{l}\text { Interest rate spread (lending rate } \\
\text { minus deposit rate, \%) }\end{array}$ & IRS & 6.9 & 5.8 & 7.7 & -22.5 & 49.6 \\
\hline $\begin{array}{l}\text { Risk premium on lending (lending } \\
\text { rate minus treasury bill rate, } \% \text { ) }\end{array}$ & RPL & 5.8 & 4.8 & 9.3 & -33.6 & 49.3 \\
\hline
\end{tabular}

Source: Authors' own calculations

The specification of Equations 1-4 is based on regressing the current level of debt and other independent variables on the 5-year forward-looking overlapping average per capita GDP growth rate. This strategy allows addressing several problems. The first one is related to the fact that estimates based on annual per capita GDP growth are highly affected by the cyclical patterns of economic fluctuations. The second one is that averaged future values can, to some degree, prevent a reverse causality and mitigate the endogeneity bias 
in Equations 1-4 since current growth rates (or the expected growth rate over the next year) affect debt, just like debt affects growth rates. Although this strategy increases the sample size significantly compared to non-overlapping growth episodes, it also introduces a moving average structure into the error term. Following Panizza and Presbitero (2014), for the general estimations, we use the Huber-White Sandwich correction in the least square dummy variable (LSDV) estimator setting, which allows modelling the autocorrelation in the error term.

The robustness check of the general findings includes three components. The first one is related to the alternative strategy to examine the effect of the uncertainty on the debtgrowth relationship. It is implemented by splitting the sample into two groups based on the values of IRS and comparing estimated linear (Equation 1) and quadratic (Equation 3) debt-growth relationships between groups with relatively low and relatively high IRS. The second one is based on estimating the same multiplicative Equations 2 and 4, using an alternative system generalised method of moments (SGMM) estimator, which more rigorously addresses the possible endogeneity bias of the debt and other right-hand side variables by introducing internally predetermined instrumental variables (IV). The third one is based on using alternative variables to proxy uncertainty in our general multiplicative setting.

\section{Estimation Results and Robustness Check}

All the LSDV estimates of Equations 1-4 presented in Table 2 satisfy general statistical properties and, in this sense, are valid. In terms of their size and sign, the estimated coefficients on regressors are consistent with empirical growth literature and are reasonable from the theoretical point of view. The results are comparable across all the estimations. We find that less developed countries are growing faster than the more advanced ones, and the speed of the conditional beta-convergence is around $1 \%$. It means that by retaining the same convergence rate, cross-country differences will shrink by half approximately after 69 years. Our findings show that effective governance, accumulation of human capital, investments in gross capital formation and trade openness have a positive and statistically significant effect on growth. In contrast, the increasing share of the government sector in the economy and inflation slow down economic growth significantly. We do not find statistically significant evidence that population change would affect growth. 
Table 2: General estimates based on LSDV

\begin{tabular}{|c|c|c|c|c|c|c|}
\hline \multicolumn{2}{|l|}{ Estimation } & $\mathbf{I}$ & II & III & IV & $\mathbf{v}$ \\
\hline \multicolumn{2}{|l|}{$\begin{array}{l}\text { Regressor/Coefficient/ } \\
\text { Equation }\end{array}$} & \multicolumn{2}{|c|}{ Equation 1} & Equation 2 & Equation 3 & Equation 4 \\
\hline Intercept & $a$ & $\begin{array}{l}0.0858^{* * *} \\
(0.0138)\end{array}$ & $\begin{array}{l}0.0913^{* * *} \\
(0.0144)\end{array}$ & $\begin{array}{l}0.0843^{* * *} \\
(0.0146)\end{array}$ & $\begin{array}{l}0.0870^{* * *} \\
(0.0146)\end{array}$ & $\begin{array}{l}0.0716^{* * *} \\
(0.0180)\end{array}$ \\
\hline $\begin{array}{l}\text { Initial per capita GDP } \\
(\operatorname{InY})\end{array}$ & $\beta_{1}$ & $\begin{array}{l}-0.0101^{* * *} \\
(0.0011)\end{array}$ & $\begin{array}{l}-0.0106^{* * *} \\
(0.0011)\end{array}$ & $\begin{array}{l}-0.0105^{* * *} \\
(0.0011)\end{array}$ & $\begin{array}{l}-0.0106^{* * *} \\
(0.0011)\end{array}$ & $\begin{array}{l}-0.0105^{* * *} \\
(0.0012)\end{array}$ \\
\hline $\begin{array}{l}\text { Institutions } \\
\text { (GE) }\end{array}$ & $\beta_{2}$ & $\begin{array}{l}0.0056^{* * *} \\
(0.0015)\end{array}$ & $\begin{array}{l}0.0059^{* * *} \\
(0.0015)\end{array}$ & $\begin{array}{l}0.0065^{* * * *} \\
(0.0015)\end{array}$ & $\begin{array}{l}0.0063^{* * *} \\
(0.0015)\end{array}$ & $\begin{array}{l}0.0068^{* * *} \\
(0.0015)\end{array}$ \\
\hline $\begin{array}{l}\text { Government size } \\
\text { (InG) }\end{array}$ & $\beta_{3}$ & $\begin{array}{l}-0.0077^{* * *} \\
(0.0020)\end{array}$ & $\begin{array}{l}-0.0071^{* * *} \\
(0.0021)\end{array}$ & $\begin{array}{l}-0.0065^{* * *} \\
(0.0021) \\
\end{array}$ & $\begin{array}{l}-0.0073^{* * *} \\
(0.0021) \\
\end{array}$ & $\begin{array}{c}-0.0068^{* * *} \\
(0.0021)\end{array}$ \\
\hline $\begin{array}{l}\text { Human capital } \\
\text { (InS) }\end{array}$ & $\beta_{4}$ & $\begin{array}{l}0.0047^{* *} \\
(0.0023)\end{array}$ & $\begin{array}{l}0.0052^{* *} \\
(0.0023)\end{array}$ & $\begin{array}{l}0.0047^{* *} \\
(0.0023)\end{array}$ & $\begin{array}{l}0.0048^{* *} \\
(0.0023)\end{array}$ & $\begin{array}{l}0.0047^{* *} \\
(0.0024) \\
\end{array}$ \\
\hline $\begin{array}{l}\text { Population growth } \\
\text { ( } \Delta \text { InPOP) }\end{array}$ & $\beta_{5}$ & $\begin{array}{l}-0.0001 \\
(0.0016) \\
\end{array}$ & $\begin{array}{l}-0.0004 \\
(0.0016) \\
\end{array}$ & $\begin{array}{l}-0.0008 \\
(0.0016) \\
\end{array}$ & $\begin{array}{c}0.0005 \\
(0.0017) \\
\end{array}$ & $\begin{array}{c}0.0006 \\
(0.0017) \\
\end{array}$ \\
\hline $\begin{array}{l}\text { Inflation } \\
(\Delta \ln C P I)\end{array}$ & $\beta_{6}$ & $\begin{array}{l}-0.0245^{* *} \\
(0.0122)\end{array}$ & $\begin{array}{l}-0.0260^{* *} \\
(0.0122)\end{array}$ & $\begin{array}{l}-0.0274^{* *} \\
(0.0128) \\
\end{array}$ & $\begin{array}{l}-0.0279 * * \\
(0.0123)\end{array}$ & $\begin{array}{c}-0.0266^{* *} \\
(0.0128) \\
\end{array}$ \\
\hline $\begin{array}{l}\text { Investments } \\
\text { (InGCF) }\end{array}$ & $\beta_{7}$ & $\begin{array}{l}0.0085^{* * *} \\
(0.0023)\end{array}$ & $\begin{array}{l}0.0084^{* * *} \\
(0.0023)\end{array}$ & $\begin{array}{l}0.0087^{* * *} \\
(0.0023)\end{array}$ & $\begin{array}{l}0.0071^{* * *} \\
(0.0024)\end{array}$ & $\begin{array}{l}0.0078^{* * *} \\
(0.0024)\end{array}$ \\
\hline $\begin{array}{l}\text { Trade openness } \\
\text { (InT) }\end{array}$ & $\beta_{8}$ & $\begin{array}{l}0.0048^{* * *} \\
(0.0005)\end{array}$ & $\begin{array}{l}0.0048^{* * *} \\
(0.0005)\end{array}$ & $\begin{array}{l}0.0047^{* * *} \\
(0.0005) \\
\end{array}$ & $\begin{array}{l}0.0049^{* * *} \\
(0.0005)\end{array}$ & $\begin{array}{l}0.0047^{* * *} \\
(0.0005)\end{array}$ \\
\hline $\begin{array}{l}\text { Debt } \\
(\operatorname{InD} D)\end{array}$ & $\beta_{9}$ & $\begin{array}{l}- \\
-\end{array}$ & $\begin{array}{l}-0.0012 \\
(0.0009)\end{array}$ & $\begin{array}{l}0.0003 \\
(0.0012)\end{array}$ & $\begin{array}{l}0.0041^{* *} \\
(0.0020)\end{array}$ & $\begin{array}{c}0.0097 \\
(0.0050)\end{array}$ \\
\hline $\begin{array}{l}\text { Debt } \times \text { uncertainty } \\
(\operatorname{InD} \times \operatorname{IRS})\end{array}$ & $\beta_{10}$ & $\begin{array}{l}- \\
-\end{array}$ & $\begin{array}{l}- \\
-\end{array}$ & $\begin{array}{l}-0.0003^{* *} \\
(0.0001)\end{array}$ & $\begin{array}{l}- \\
-\end{array}$ & $\begin{array}{l}0.0012^{*} \\
(0.0007)\end{array}$ \\
\hline $\begin{array}{l}\text { Uncertainty } \\
\text { (IRS) }\end{array}$ & $\beta_{11}$ & - & $\begin{array}{l}- \\
-\end{array}$ & $\begin{array}{c}-0.0013^{* *} \\
(0.0006)\end{array}$ & - & $\begin{array}{c}-0.0015^{* *} \\
(0.0007)\end{array}$ \\
\hline $\begin{array}{l}\text { Squared debt } \\
\left([\ln D]^{2}\right)\end{array}$ & $\beta_{12}$ & $\begin{array}{l}- \\
-\end{array}$ & $\begin{array}{l}- \\
-\end{array}$ & $\begin{array}{l}- \\
-\end{array}$ & $\begin{array}{c}-0.0005^{*} \\
(0.0003)\end{array}$ & $\begin{array}{l}-0.0014^{*} \\
(0.0008)\end{array}$ \\
\hline $\begin{array}{l}\text { Sq. debt } \times \text { uncertainty } \\
\left([\operatorname{lnD}]^{2} \times[R S)\right.\end{array}$ & $\beta_{13}$ & $\begin{array}{l}- \\
-\end{array}$ & $\begin{array}{ll}- \\
-\end{array}$ & $\begin{array}{l}- \\
-\end{array}$ & $\begin{array}{l}- \\
-\end{array}$ & $\begin{array}{l}-0.0002^{*} \\
(0.0001)\end{array}$ \\
\hline \multicolumn{2}{|l|}{ Sample size } & 924 & 924 & 924 & 924 & 924 \\
\hline \multicolumn{2}{|l|}{ Within $R^{2}$} & 0.3501 & 0.3506 & 0.3541 & 0.3524 & 0.3552 \\
\hline \multicolumn{2}{|l|}{ LSDV $R^{2}$} & 0.7710 & 0.7649 & 0.7648 & 0.7707 & 0.7813 \\
\hline \multicolumn{2}{|l|}{ Pesaran CD test ${ }^{(1)}[p$-value $]$} & [0.2683] & {$[0.2578]$} & [0.2994] & {$[0.2736]$} & {$[0.2830]$} \\
\hline \multicolumn{2}{|l|}{$\begin{array}{l}\text { Test for differing group } \\
\text { intercepts }{ }^{(2)}[p \text {-value }]\end{array}$} & {$[<0.001]$} & {$[<0.001]$} & {$[<0.001]$} & {$[<0.001]$} & {$[<0.001]$} \\
\hline \multicolumn{2}{|l|}{ Wald test ${ }^{(3)}[p$-value] } & {$[<0.001]$} & {$[<0.001]$} & {$[<0.001]$} & {$[<0.001]$} & {$[<0.001]$} \\
\hline \multicolumn{2}{|l|}{ Hausman test $^{(4)}[p$-value] } & {$[<0.001]$} & {$[<0.001]$} & {$[<0.001]$} & {$[<0.001]$} & {$[<0.001]$} \\
\hline \multicolumn{2}{|c|}{ Wooldridge test ${ }^{(5)}[p$-value] } & 0.0834 & 0.0902 & 0.0870 & 0.0816 & 0.0844 \\
\hline \multicolumn{2}{|l|}{ Turning point } & - & - & - & 61 & - \\
\hline
\end{tabular}

Note:

(1) A low $p$-value counts against the null hypothesis: cross-sectional independence.

(2) A low $p$-value counts against the null hypothesis: the groups have a common intercept, i.e., OLS outperforms LSDV.

(3) A low $p$-value counts against the null hypothesis: no time effects, i.e., time dummies are irrelevant.

(4) A low $p$-value counts against the GLS estimates with random effects in favour of LSDV.

(5) A low $p$-value counts against the null hypothesis: no first-order serial correlation in error terms. Heteroscedasticity robust standard errors are presented in parentheses. All estimations include time and country fixed effects and are based on LSDV with a Huber-White Sandwich correction.

$*, * * * *$ indicates significant at the 10,5 and 1 per cent level, respectively.

Source: Authors' own calculations 
The linear specification of Equation 1 does not reveal (see Est. II) a statistically significant debt-growth relationship. It could be due to the fact that the effect of debt on growth is not constant, i.e., heterogeneous and dependent on the macroeconomic conditions. The multiplicative specification of Equation 2 with the IRS as a moderator in the linear debt-growth nexus revealed (see Est. III) that the IRS related to the uncertainty level in the economy negatively mediates the effect of debt on growth. Since the estimated coefficient on the interaction term between debt and IRS is negative, we can conclude that the higher the IRS, the smaller positive (and the bigger negative) debt effect on growth is observed (see Figure 1, part a). A positive but statistically insignificant debt effect on growth is observed when the IRS ranges from $-23 \%$ to $1 \%$. The effect becomes negative but still statistically insignificant when the IRS exceeds $1 \%$ and statistically significant when it exceeds $7 \%$.

All the above interpretations assume that the debt-growth nexus remains constant as the size of the debt changes. However, this assumption does not hold as Est. IV of quadratic specification shows that the effect of debt on growth is not constant. The marginal impact of debt on growth remains positive if the debt-to-GDP ratio does not exceed $61 \%$ and becomes negative if this threshold level is exceeded. To some extent, this finding could explain why we do not find a significant debt-growth relationship in the linear specification since positive and negative marginal effects offset each other in the linear setting.

Figure 1, part b) presents the quadratic relationship between debt and growth mediated by IRS based on Equation 4 and Est. V. The plotted curve represents the quadratic debt-growth nexus at the discrete level of IRS, one at the mean value of IRS and others at the values that stray from the mean up to three standard deviations. Results show that the smaller the IRS, the bigger the positive effect of debt on growth and the higher the turning point in the debt-growth nexus. For example, when the IRS is above its average value by one standard deviation, the tipping point in the debt-growth nexus is at about $110 \%$ of the debt-to-GDP ratio. In contrast, if the IRS is below its average value by between one and three standard deviations, the tipping point increases up to $150 \%$ and $180 \%$ of the debt-to-GDP ratio, respectively. These findings are in line with previous studies which investigated the relationship between public debt and growth in large panel data sets and found evidence for a varying debt threshold across countries (Caner et al., 2010; Afonso and Jalles, 2013; Kourtellos et al., 2013; Eberhardt and Presbitero, 2015; Duygu, 2018; Koroglu, 2019; Swamy 2020; Mohd Daud, 2020). 
Figure 1: Mediating effect of interest rate spread on debt-growth relationship based on LSDV estimates

a) Linear relationship based on Equation 2 and Est. III

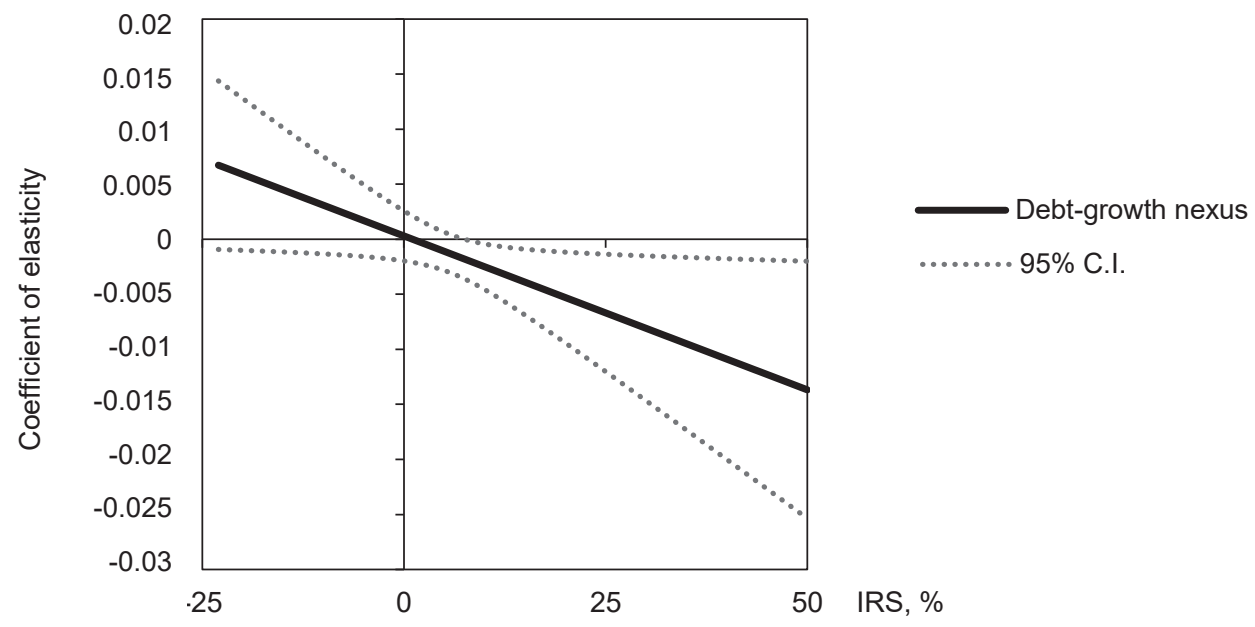

b) Quadratic relationship based on Equation 4 and Est. V

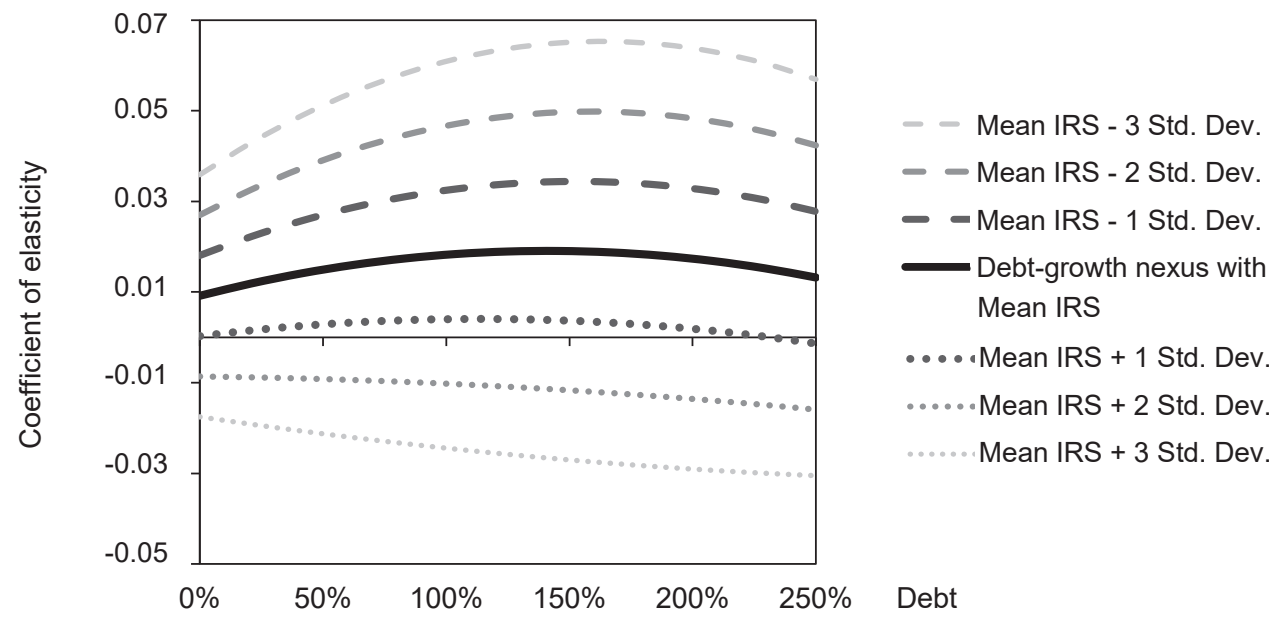

Source: Authors' own calculations 
Our results suggest that the level of uncertainty may be one of the factors explaining the observed threshold variation across countries. High debt levels increase uncertainty, which might lead to higher borrowing costs and lower economic growth. However, there is no consensus on what levels of debt investors consider "high" enough to start to require risk premium. Besides debt level, many other country-specific uncertainty factors (institutional environment, macroeconomic conditions, financial sector stability) can cause a level of uncertainty. Our results show that high debt can affect economic growth positively if investors do not consider that debt is risky and do not require a risk premium. On the other hand, we may expect very low levels of debt to hinder output growth if the level of uncertainty is high.

\section{Figure 2: Turning points in debt-growth relationship}

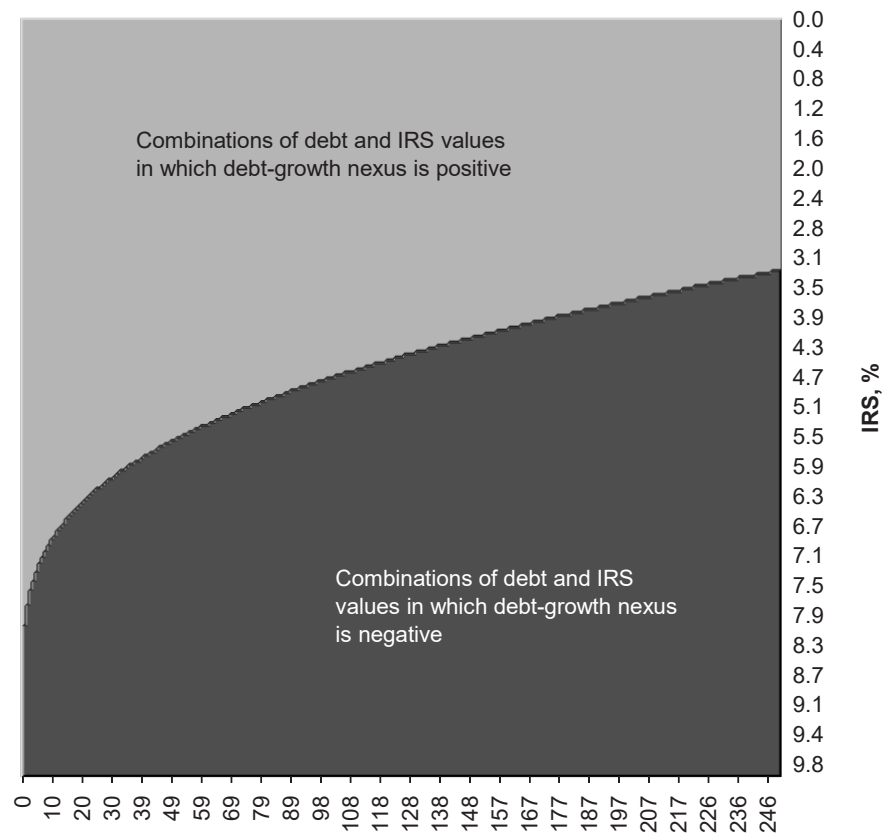

Debt, \%

Source: Authors' own calculations

Since the specification of Equation 4 assumes that the debt-growth nexus depends on the level of debt and IRS, Figure 2 shows in what combinations of IRS and debt values (in a manner of continuous variables) the debt-growth nexus is positive/negative. The results show that the turning points from a positive to a negative debt-growth 
relationship and vice versa lie in a narrow range of IRS values, namely from $3 \%$ to $8 \%$, but this range covers around $55 \%$ of all observations. We see that if the IRS is bigger than $8 \%$, the negative effect of debt on growth is observed at all debt levels. On the contrary, IRS being below $3 \%$ ensures that the debt-growth nexus is positive irrespective of debt level. We should add here that a statistically significant negative effect starts to manifest for a high debt if the IRS exceeds 14\%, and when the IRS gets higher, proportionally lower debt rates become associated with a statistically significant negative effect of growth. Considering the positive effect, it becomes statistically significant only if the debt-to-GDP ratio is below $67 \%$ and the IRS is negative.

A robustness check revealed findings consistent with the general estimations (see Table A in the Appendix). After splitting the sample into two groups based on the median level of the IRS (5.79\%), the linear specification of Equation 1 shows a positive but insignificant debt-growth relationship when the IRS values are below the median level (see Est. VI), and a statistically significant negative effect of debt on growth when the IRS values are above the median level (see Est. VII). The quadratic specification of Equation 3 shows an inverted U-shaped debt-growth relationship with a turning point at $72 \%$ of the debt-to-GDP ratio when the IRS values are below the median level (see Est. VIII). It means that relatively small debt in a low-uncertainty environment has a positive marginal effect on growth, while high debt levels still constrain economic growth. In a high-uncertainty environment, the debtgrowth relationship remains negative irrespective of the debt levels (see Est. XIX).

To address potential endogeneity bias more rigorously, we used 2-step SGMM as the alternative estimator. After computing the 1-step estimator, we used the sample covariance matrix of the estimated residuals to obtain 2-step estimates, which are consistent and asymptotically efficient. To consider the concern of Blundell and Bond (1998) about the downward-biased tendency of standard errors estimated by the SGMM approach for small samples, we used finite-sample corrections suggested by Windmeijer (2005) to the asymptotic covariance matrix of the parameters, which are nowadays used almost universally. Estimations X and XI based on SGMM revealed the same moderating effect of uncertainty in the framework of the linear (Equation 2) and quadratic (Equation 4) debt-growth relationship as the LSDV estimates (see Est. III and V in Table 2). However, the estimated coefficients are significant at a higher confidence level. Figure A1 in the Appendix plots the estimated relationships.

The LSDV estimates with risk premium on lending as an alternative variables to proxy the uncertainty channel revealed similar results (see Est. XII - XII and Figure 2A). A higher uncertainty level associated with a higher risk premium on lending leads to a lower positive and bigger negative effect of debt on growth in both the linear and quadratic specifications. 


\section{Conclusions}

Over the last ten years, there has been an intensive search for the factors that shape the debt-growth relationship. Although scholars still do not agree whether this relation is linear or non-linear, the present debate concentrates around conditions that determine the tipping point above which debt starts to restrict growth. Research finds that variation in this threshold across countries could be explained to some extent by institutional quality (government effectiveness, rule of law, control of corruption, political stability, etc.). However, the results show that the debt threshold also varies in countries with similar institutional environments, which raises the need to look for other explanatory factors.

This paper contributes to scarce empirical evidence on factors that shape the effect of debt on growth by examining uncertainty as one of the factors that cause heterogeneity of this relationship.

Our empirical analysis is grounded on the neoclassical growth model, which, with different modifications, has become a conventional tool to analyse factors that affect the debt-growth nexus. Our specifications allow uncertainty to mediate the linear and non-linear debt effects on growth. The derived conditional composite slope coefficients and standard errors associated with them allowed us to examine the debt-growth nexus under different uncertainty conditions. Since one part of uncertainty is financial risk, which is closely related to the financial sector stability, we used interest rate spread and risk premium on lending to proxy uncertainty.

The different estimation strategies and alternative variables used to proxy uncertainty revealed consistent empirical evidence that a higher uncertainty level is related to a smaller positive and a bigger negative debt effect on growth. We do not find solid statistical evidence that a low level of uncertainty would lead to positive growth outcomes of debt irrespective of indebtedness. More precisely, although the linear specification revealed an insignificant positive effect of debt on growth when uncertainty is low, the non-linear specification, which accounts for the level of debt, revealed that a significant impact is probable only if low uncertainty accompanies a low level of debt. The estimated conditional threshold level in the debt-growth nexus lies in the range of debt and uncertainty values common to most of the examined countries. Therefore, our findings propose a policy tool to evaluate the growth effect of debt change having a particular uncertainty level, or how a changing uncertainty level would affect the debt-growth nexus having a specific level of indebtedness.

As for the limitations of our paper, we analyse uncertainty as one of the factors that affect the debt-growth nexus, not covering such risk aspects as population aging or action taken by central banks during periods of high uncertainty, which may have influenced variables used in this study and hide, to some extent, the actual level of uncertainty, etc. 
The variables used for the approximation of uncertainty can reflect not only uncertainty but also the health of the financial sector and its development, etc. We expect that a higher uncertainty leads to an increase in the interest rate spread. However, this may not be the case if a country's financial sector is competitive. Therefore, our results may be underestimated, so more detailed research is needed in the future.

\section{Appendix}

\section{Table A: Robustness check}

\begin{tabular}{|c|c|c|c|c|c|c|c|c|c|}
\hline \multicolumn{2}{|l|}{ Estimation } & (VI) & (VII) & (VIII) & (IX) & (X) & (XI) & (XII) & (XIII) \\
\hline \multirow{2}{*}{\multicolumn{2}{|c|}{ Estimator }} & \multirow{2}{*}{\multicolumn{4}{|c|}{$\operatorname{LSDV}^{(8)}$}} & \multirow{2}{*}{\multicolumn{2}{|c|}{$\begin{array}{l}\text { SGMM }^{(9)} \text { with IRS } \\
\text { as proxy } \\
\text { for uncertainty }\end{array}$}} & \multicolumn{2}{|c|}{ LSDV $^{(8)}$} \\
\hline & & & & & & & & \multicolumn{2}{|c|}{$\begin{array}{c}\text { RPL as proxy } \\
\text { for uncertainty }\end{array}$} \\
\hline \multicolumn{2}{|l|}{ Equation } & \multicolumn{2}{|c|}{ Equation 1} & \multicolumn{2}{|c|}{ Equation 3} & Equation 2 & Equation 4 & Equation 2 & Equation 4 \\
\hline \multicolumn{2}{|l|}{$\begin{array}{l}\text { Regressor/ } \\
\text { Coefficient }\end{array}$} & IRS $<5.79$ & IRS $>5.79$ & $\mathrm{IRS}<5.79$ & IRS $>5.79$ & - & - & - & - \\
\hline \multirow{2}{*}{$Y(-1)$} & & - & - & - & - & $0.6812^{* * *}$ & $0.6633^{* * *}$ & - & - \\
\hline & & - & - & - & - & $(0.0544)$ & $(0.0542)$ & - & - \\
\hline \multirow{2}{*}{ Intercept } & \multirow{2}{*}{$a$} & $0.0938^{* * *}$ & $0.0822^{* * *}$ & $0.0936^{* * *}$ & $0.0793^{* * *}$ & $0.0883^{* * *}$ & $0.0762^{* * *}$ & $0.0824^{* * *}$ & $0.0783^{* * *}$ \\
\hline & & $(0.0197)$ & $(0.0224)$ & $(0.0197)$ & $(0.0305)$ & $(0.0218)$ & $(0.0193$ & $(0.0182)$ & (0.0258) \\
\hline \multirow{2}{*}{$\begin{array}{l}\text { Initial per } \\
\text { capita GDP } \\
(\operatorname{InY} Y)\end{array}$} & \multirow{2}{*}{$\beta_{1}$} & $-0.0114^{* * *}$ & $-0.0098^{* * *}$ & $-0.0114^{* * *}$ & $-0.0094^{* * *}$ & $-0.0089^{* * *}$ & $-0.0092^{* * *}$ & $-0.0074^{* * *}$ & $-0.0073^{* * *}$ \\
\hline & & $(0.0017)$ & (0.0016) & $(0.0017)$ & $(0.0016)$ & $(0.0016)$ & $(0.0019)$ & $(0.00150)$ & $(0.00150)$ \\
\hline \multirow{2}{*}{$\begin{array}{l}\text { Institutions } \\
\text { (GE) }\end{array}$} & \multirow{2}{*}{$\beta_{2}$} & $0.0071^{* * *}$ & $0.0039 * * *$ & $0.0070^{* * *}$ & $0.0036^{* * *}$ & $0.0047^{* * *}$ & $0.0048^{* * *}$ & $0.0046^{* *}$ & $0.0049^{* *}$ \\
\hline & & $(0.0021)$ & $(0.0015)$ & $(0.0021)$ & $(0.0014)$ & $(0.0012)$ & $(0.0019)$ & $(0.0019)$ & $(0.0019)$ \\
\hline \multirow{2}{*}{$\begin{array}{l}\text { Government } \\
\text { size } \\
(\operatorname{InG})\end{array}$} & \multirow{2}{*}{$\beta_{3}$} & $-0.0065^{* *}$ & $-0.0074^{* *}$ & $-0.0064^{* *}$ & $-0.0072^{* *}$ & $-0.0068^{* *}$ & $-0.0070^{* *}$ & $-0.0066^{* * *}$ & $-0.0069^{* * *}$ \\
\hline & & $(0.0029)$ & $(0.0031)$ & $(0.0030)$ & $(0.0031)$ & $(0.0033)$ & $(0.0034)$ & $(0.0023)$ & $(0.0024)$ \\
\hline \multirow{2}{*}{$\begin{array}{l}\text { Human } \\
\text { capital } \\
\text { (InS) }\end{array}$} & \multirow{2}{*}{$\beta_{4}$} & $0.0052^{* *}$ & $0.0045^{* *}$ & $0.0055^{* *}$ & $0.0042^{* *}$ & $0.0181^{* * *}$ & $0.0178^{* * *}$ & $0.0042^{* *}$ & $0.0045^{* *}$ \\
\hline & & $(0.0028)$ & $(0.0022)$ & $(0.0025)$ & $(0.0024)$ & $(0.0047)$ & $(0.0047)$ & $(0.0017)$ & $(0.0018)$ \\
\hline \multirow{2}{*}{$\begin{array}{l}\text { Population } \\
\text { growth } \\
(\Delta \text { InPOP) }\end{array}$} & \multirow[b]{2}{*}{$\beta_{5}$} & 0.0003 & -0.0004 & 0.0002 & -0.0004 & 0.0067 & 0.0083 & 0.0012 & 0.0017 \\
\hline & & $(0.0002)$ & $(0.0003)$ & $(0.0002)$ & $(0.0003)$ & $(0.0061)$ & $(0.0062)$ & $(0.0019)$ & $(0.0021)$ \\
\hline \multirow{2}{*}{$\begin{array}{l}\text { Inflation } \\
(\Delta \operatorname{lnCPI})\end{array}$} & \multirow{2}{*}{$\beta_{6}$} & -0.0186 & $-0.0467^{* * *}$ & -0.0193 & $-0.0504^{* * *}$ & $-0.01329 * *$ & $-0.01422^{* *}$ & $0.0131^{* *}$ & $0.0138^{* *}$ \\
\hline & & $(0.0202)$ & $(0.0159)$ & $(0.0203)$ & $(0.0158)$ & $(0.0053)$ & $(0.0062)$ & $(0.0069)$ & $(0.0069)$ \\
\hline \multirow{2}{*}{$\begin{array}{l}\text { Investments } \\
\text { (InGCF) }\end{array}$} & \multirow{2}{*}{$\beta_{7}$} & $0.0130^{* * *}$ & $0.0061^{*}$ & $0.0141^{* * *}$ & $0.0058^{*}$ & $0.0069^{* *}$ & $0.0075^{* * *}$ & $0.0077^{* *}$ & $-0.0072^{* *}$ \\
\hline & & $(0.0034)$ & $(0.0034)$ & $(0.0038)$ & $(0.0033)$ & $(0.0028)$ & $(0.0029)$ & $(0.0030)$ & $(0.0031)$ \\
\hline \multirow{2}{*}{$\begin{array}{l}\text { Trade } \\
\text { openness } \\
\text { (InT) }\end{array}$} & \multirow{2}{*}{$\beta_{8}$} & $0.0032^{* * *}$ & $0.0048^{* * *}$ & $0.0032^{* * *}$ & $0.0048^{* * *}$ & $0.0063^{* * *}$ & $0.0058^{* * *}$ & $0.0067^{* * *}$ & $-0.0068^{* * *}$ \\
\hline & & $(0.0006)$ & $(0.0009)$ & $(0.0006)$ & $(0.0010)$ & $(0.0008)$ & $(0.0008)$ & $(0.0007)$ & $(0.0007)$ \\
\hline \multirow{2}{*}{$\begin{array}{l}\text { Debt } \\
(\ln D)\end{array}$} & \multirow{2}{*}{$\beta_{9}$} & 0.0008 & $-0.0037^{* *}$ & $0.0233^{* *}$ & $-0.0032^{* *}$ & 0.0020 & $0.0266^{* * *}$ & 0.0029 & 0.0252 \\
\hline & & $(0.0011)$ & $(0.0015)$ & $(0.0107)$ & $(0.0016)$ & $(0.0018)$ & $(0.0071)$ & $(0.0024)$ & $(0.0184)$ \\
\hline
\end{tabular}


Table A: Continuation

\begin{tabular}{|c|c|c|c|c|c|c|c|c|c|}
\hline \multirow{2}{*}{$\begin{array}{l}\text { Debt } \times \\
\text { uncertainty }\end{array}$} & \multirow{2}{*}{$\beta_{10}$} & - & - & - & - & $-0.0004^{* * *}$ & $0.0031^{* * *}$ & $-0.0003^{* *}$ & 0.0024 \\
\hline & & - & - & - & - & $(0.0001)$ & $(0.0010)$ & $(0.0001)$ & $(0.0019)$ \\
\hline \multirow{2}{*}{ Uncertainty } & \multirow{2}{*}{$\beta_{11}$} & - & - & - & - & $-0.0015^{* * *}$ & $-0.0069 * * *$ & $-0.0012^{* *}$ & -0.0025 \\
\hline & & - & - & - & - & $(0.0005)$ & $(0.0020)$ & $(0.0006)$ & $(0.0030)$ \\
\hline \multirow{2}{*}{$\begin{array}{l}\text { Squared } \\
\text { debt } \\
\left([\operatorname{lnD}]^{2}\right)\end{array}$} & \multirow[b]{2}{*}{$\beta_{12}$} & - & - & $-0.0027^{* *}$ & -0.0004 & - & $-0.0035^{* * *}$ & - & $-0.0013^{*}$ \\
\hline & & - & - & $(0.0014)$ & $(0.0006)$ & - & $(0.0010)$ & - & $(0.0008)$ \\
\hline \multirow{2}{*}{$\begin{array}{l}\text { Sq. debt } \times \\
\text { uncertainty }\end{array}$} & \multirow{2}{*}{$\beta_{13}$} & - & - & - & - & - & $-0.0003^{* * *}$ & - & $-0.0002^{*}$ \\
\hline & & - & - & - & - & - & $(0.0001)$ & - & $(0.0001)$ \\
\hline \multicolumn{2}{|l|}{ Sample size } & 463 & 461 & 463 & 461 & 820 & 820 & 509 & 509 \\
\hline \multicolumn{2}{|l|}{ Within $R^{2}$} & 0.3856 & 0.3346 & 0.3848 & 0.3428 & - & - & 0.3646 & 0.3626 \\
\hline \multicolumn{2}{|l|}{ LSDV $R^{2}$} & 0.7541 & 0.6980 & 0.7532 & 0.7070 & - & - & 0.6563 & 0.6624 \\
\hline \multicolumn{2}{|c|}{$\begin{array}{l}\text { Pesaran CD test }{ }^{(1)} \\
\text { [p-value] }\end{array}$} & {$[0.3219]$} & {$[0.2835]$} & {$[0.3592]$} & [0.3009] & - & - & {$[0.3113]$} & {$[0.3219]$} \\
\hline \multicolumn{2}{|c|}{$\begin{array}{l}\text { Test for differing } \\
\text { group } \\
\text { intercepts }^{(2)} \\
\text { [p-value] }\end{array}$} & {$[<0.001]$} & {$[<0.001]$} & {$[<0.001]$} & {$[<0.001]$} & - & - & {$[<0.001]$} & {$[<0.001]$} \\
\hline \multicolumn{2}{|l|}{$\begin{array}{l}\text { Wald test }{ }^{(3)} \\
\text { [p-value] }\end{array}$} & {$[<0.001]$} & {$[<0.001]$} & {$[<0.001]$} & {$[<0.001]$} & - & - & {$[<0.001]$} & {$[<0.001]$} \\
\hline \multicolumn{2}{|c|}{$\begin{array}{l}\text { Hausman test }{ }^{(4)} \\
\text { [p-value] }\end{array}$} & {$[<0.001]$} & {$[<0.001]$} & {$[<0.001]$} & {$[<0.001]$} & - & - & {$[<0.001]$} & {$[<0.001]$} \\
\hline \multicolumn{2}{|c|}{$\begin{array}{l}\text { Wooldridge test }{ }^{(5)} \\
\text { [p-value] }\end{array}$} & {$[0.0959]$} & {$[0.1037]$} & {$[0.1005]$} & {$[0.0938]$} & - & - & {$[0.0970]$} & {$[0.0957]$} \\
\hline \multicolumn{2}{|c|}{$\begin{array}{l}\text { Number } \\
\text { of instruments }\end{array}$} & - & - & - & - & 88 & 95 & - & - \\
\hline \multicolumn{2}{|l|}{$\begin{array}{l}\text { Sargan test }{ }^{(6)} \\
\text { [p-value] }\end{array}$} & - & - & - & - & {$[0.2754]$} & {$[0.2602]$} & - & - \\
\hline \multicolumn{2}{|l|}{$\begin{array}{l}\text { AR(2) test }{ }^{(7)} \\
{[p \text {-value] }}\end{array}$} & - & - & - & - & {$[0.1846]$} & {$[0.1759]$} & - & - \\
\hline \multicolumn{2}{|l|}{ Turning point } & - & - & 72 & - & - & - & - & - \\
\hline
\end{tabular}

Note:

(1) A low $p$-value counts against the null hypothesis: cross-sectional independence.

(2) A low $p$-value counts against the null hypothesis: the groups have a common intercept, i.e., OLS outperforms LSDV.

(3) A low $p$-value counts against the null hypothesis: no time effects, i.e., time dummies are irrelevant.

(4) A low $p$-value counts against the GLS estimates with random effects in favour of LSDV.

(5) A low $p$-value counts against the null hypothesis: no first-order serial correlation in error terms.

(6) A low $p$-value counts against the null hypothesis: internally predetermined IV are valid.

(7) A low $p$-value counts against the null hypothesis: there is no second-order autocorrelation.

(8) LSDV estimator with time and country fixed effects and a Huber-White Sandwich correction. Heteroscedasticity robust standard errors are presented in parentheses.

(9) 2-step SGMM lag $(3,5)$ estimator with equations in levels and time dummies. The statistics given in the parentheses under the coefficients are Windmeijer-corrected standard errors.

$*,{ }^{* *},{ }^{* *}$ indicates significance at the 10,5 and 1 per cent level, respectively.

Source: Authors' own calculations 
Figure A1: Mediating effect of interest rate spread on debt-growth relationship based on SGMM estimates

a) Linear relationship based on Equation 2 and Est. $X$

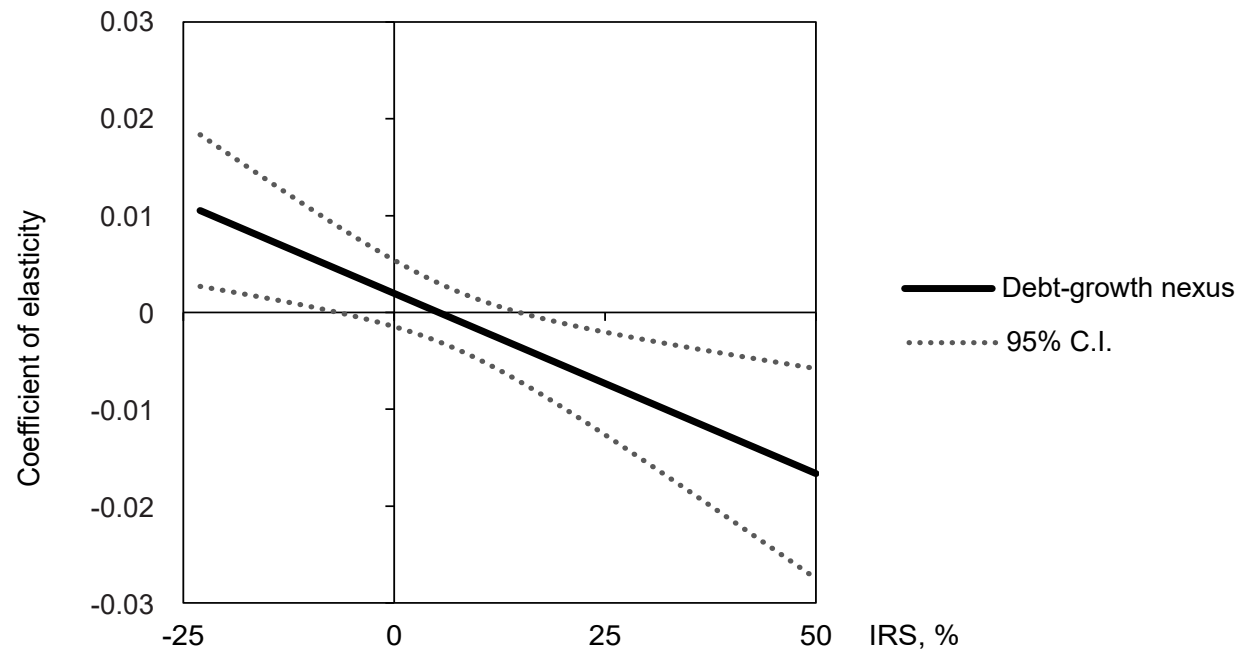

b) Quadratic relationship based on Equation 4 and Est. XI

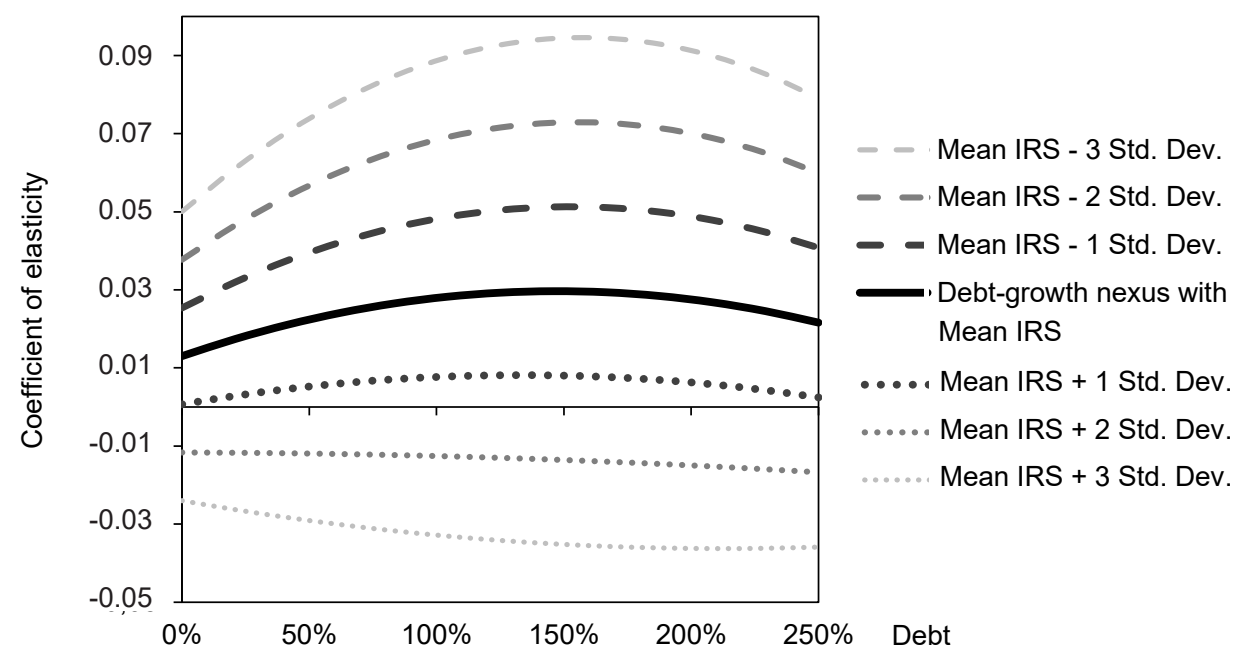

Source: Authors' own calculations 
Figure A2: Mediating effect of risk premium on lending on debt-growth relationship based on LSDV estimates

a) Linear relationship based on Equation 2 and Est. XII

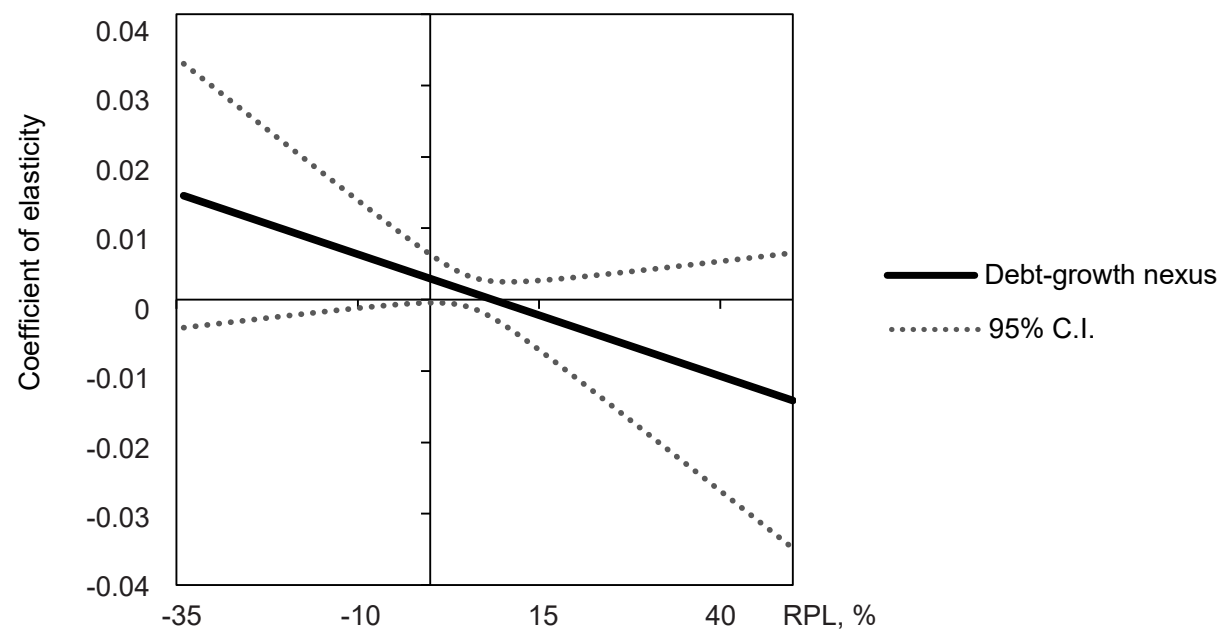

b) Quadratic relationship based on Equation 4 and Est. XIII

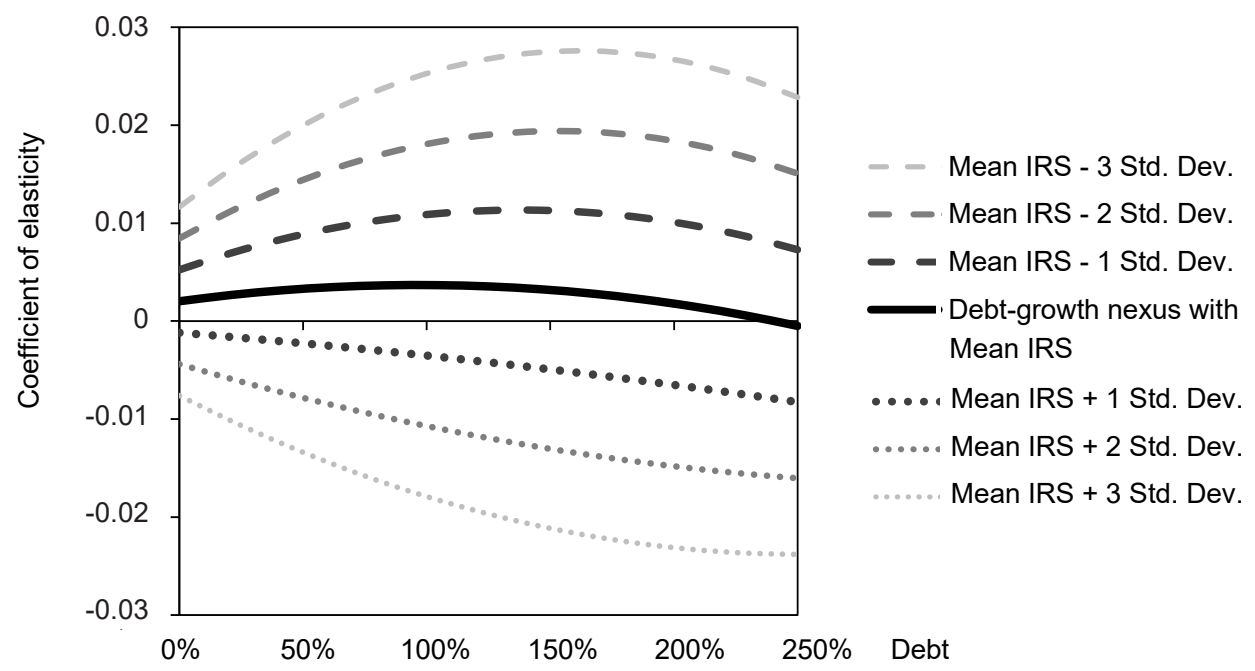

Source: Authors' own calculations 


\section{References}

Afonso, A. Jalles, J. T. (2013). Growth and Productivity: The Role of Government Debt. International Review of Economics \& Finance, 25, 384-407.

Ahlborn, M., Schweickert, R. (2018). Public debt and economic growth - economic systems matter. International Economics \& Economic Policy, 15(2), 373-403. https://doi.org/10.1007/s10368-017-0396-0

Al Shubiri, F.N., Jamil, S.A. (2017). Assessing the Determinants of Interest Spread of Commercial Banks in Oman: An Empirical Investigation. European Research Studies Journal, XX(2A), 90-108.

Alcidi, C., Gros, D. (2019). Public debt and the risk premium: a dangerous doom loop. CEPS Policy Insights. No. 2019-06, 2 2n May, 2019.

Anzuini, A., Rossi, L., Tommasino, P. (2020). Fiscal Policy Uncertainty and the Business Cycle: Time Series Evidence from Italy. Journal of Macroeconomics, 65, https://doi.org/10.1016/j. jmacro.2020.103238

Baum, Ch. B., Caglayan, M., Xu, B. (2020). The impact of uncertainty on financial institutions: A cross-country study. International Journal of Finance and Economics, https://doi.org/10.1002/ijfe.1983.

Bentour, E. M. (2020). On the public debt and growth threshold: one size does not necessarily fit all. Applied Economics, 53(11), 1280-1299. https://doi.org/10.1080/00036846.2020.18 28806.

Blanchard, O. (2019). Public Debt and Low Interest Rates. American Economic Review, 109(4), 1197-1229, https://doi.org/10.1257/aer.109.4.1197

Blundell, R., Bond, S. (1998). Initial conditions and moment restrictions in dynamic panel data models, Journal of Econometrics, 87(1), 115-143, http://doi.org/10.1016/ s0304-4076(98)00009-8.

Caner, M., Grennes, Th., Koehler-Geib, Fr. (2010). Finding the Tipping Point-When Sovereign Debt Turns Bad. Technical Report. Washington, DC: The World Bank. https://doi. org/10.1596/9780821384831_CH03

Chiu, Yi-Bin, Lee, Chien-Chiang (2017). On the impact of public debt on economic growth: Does country risk matter? Contemporary Economic Policy, 35, 751-66, https://doi.org/10.1111/coep.12228.

Duygu, Y. K. (2018). An investigation of non-linear effects of debt on growth. Journal of Economic Asymmetries. Elsevier, vol. 18(C), 1-13, 10.1016/j.jeca.2018.e00097

Eberhardt, M., Presbitero, A. F. (2015). Public debt and growth: Heterogeneity and non-linearity. Journal of International Economics, 97(1), 45-58, https://doi.org/10.1016/j. jinteco.2015.04.005

European Commission (2018), Quarterly Report on the Euro Area 17(4), Chapter I, https://ec.europa.eu/info/sites/info/files/economyfinance/ ip100_chap_i_sovereign_bond_dynamics_in_the_ea.pdf. 
Evans R.W. (2020). Public Debt, Interest Rates, and Negative Shocks. AEA Papers and Proceedings 2020, 110, 137-140, https://doi.org/10.1257/pandp.20201101.

Ferreira, M.H, Duarte, M. P.N.. (2011). Public debt and risk premium: An analysis from an emerging economy. Journal of Economic Studies. 2011, 38(2), 203-217, https://doi.org/10.1108/01443581111128424

Fetai, B. (2015). Financial Integration and Financial Development: Does Financial Integration Metter? European Research Studies Journal, 18(2), 97-106, http://doi.org/10.35808/ ersj/447

Gómez-Puig, M., \& Sosvilla-Rivero, S. (2017). Heterogeneity in the debt-growth nexus: Evidence from EMU countries. International Review of Economics \& Finance, 51, 470-486, https://doi.org/10.1016/j.iref.2017.07.008

Greenlaw, D., Hamilton, J., Hooper, P., Mishkin, F.S. (2013), Crunch Time: Fiscal Crises and the Role of Monetary Policy, NBER Working Paper Series, No. 19297.

Greiner, A. (2014), Public Debt and the Dynamics of Economic Growth. Annals of Economics and Finance, 15(1), 185-204.

Huixin, B. (2012). Sovereign default risk premia, fiscal limits, and fiscal policy. European Economic Review, 56(3), 389-410.

IMF (2017). Greece: Request for Stand-By Arrangement-Press Release; Staff Report; and Statement by the Executive Director for Greece, https://www.imf.org/en/Publications/ CR/Issues/2017/07/20/Greece-Request-for-Stand-By-Arrangement-Press-Release-StaffReport-and-Statement-by-the-45110.

Koroglu, M. (2019). Growth and Debt: An Endogenous Smooth Coefficient Approach. Journal of Risk and Financial Management, 12(1):23, https://doi.org/10.3390/jrfm12010023

Kourtellos, A., Thanasis, S., Tan, Ch.M. (2013). The effect of public debt on growth in multiple regimes. Journal of Macroeconomics, 38, 35-43, https://doi.org/10.1016/j. jmacro.2013.08.023

Law, S.H., Ng, C.H., Kutan, A. (2021) Public Debt and Economic Growth in Developing Countries: Nonlinearity and Threshold Analysis, Economic Modelling, https://doi.org/10.1016/j.econmod.2021.02.004

Lian, W., Presbitero, A. F., Wiriadinata, U. (2020). Public Debt and $\mathrm{r}$ - g at Risk. IMF Working Paper. WP/20/137

Mohd Daud, S. N. (2020). External debt, institutional quality and economic growth. Buletin Ekonomi Moneter Dan Perbankan, 23(2), 221-238, https://doi.org/10.21098/bemp. v23i2.1173

Munir, K., Mehmood, N. R. (2018). Exploring the channels and impact of debt on economics growth: evidence from South Africa. South Asia Economic Journal, 19(1), 171-191, https://doi.org/10.1177/1391561418794692.

Panizza, U., Presbitero, A.F. (2013). Public debt and economic growth in advanced economies: A survey. Swiss Journal of Economics and Statistics, 149, 175-204, https://doi.org/10.1007/BF03399388 
Panizza, U., Presbitero, A.F., (2014). Public debt and economic growth: Is there a causal effect? Journal of Macroeconomic, 41, 21-41, https://doi.org/10.1016/j.jmacro.2014.03.009 .

Pattillo, C., Poirson, H., Ricci, L. (2011). External debt and growth. Review of Economics and Institutions, 2(3), 1-30, http://dx.doi.org/10.5202/rei.v2i3.45.

Rahman, N. H. A., Ismail, S., Ridzuan, A. R., McMillan, D. (2019). How does public debt affect economic growth? A systematic review. Cogent Business \& Management, 6(1), 1-21, https://doi.org/10.1080/23311975.2019.1701339.

Rogoff, K. (2020). Falling Real Interest Rates, Rising Debt: A Free Lunch? The Journal of Policy Modelling 24 (4(July-August), 778-790, https://doi.org/10.1016/j.jpolmod.2020.03.004

Salmon, J., de Rugy, V. (2020). Debt and Growth: A Decade of Studies (April 5, 2020). Mercatus Research Paper, Available at SSRN: https://ssrn.com/abstract=3690510 or http://dx.doi.org/10.2139/ssrn.3690510

Swamy, V. (2020). Debt and growth: Decomposing the cause and effect relationship. Finance and Economics, 52(2), 141-156, https://doi.org/10.1002/ijfe.1729

Tamborini, R. (2013). Interest-Rate Spread and Public-Debt Dynamics in a Two-Country Monetary-Union Portfolio Model. Open Economies Review, 25, 243-261, https://doi.org/10.1007/s11079-013-9279-3.

Thalassinos, I.E., Venediktova, B., Staneva-Petkova, D. (2013). Way of Banking Development Abroad: Branches or Subsidiaries. International Journal of Economics and Business Administration, 1(3), 69-78, https://doi.org/ 10.35808/ijeba/19

Turner, D., Spinelli, F. (2012). Interest-rate-growth differentials and government debt dynamics. OECD Journal: Economic Studies, Volume 2012/1. http://dx.doi.org/10.1787/ eco_studies-2012-5k912k0zkhf8

Windmeijer, F. (2005). A finite sample correction for the variance of linear efficient two-step GMM estimators. Journal of Econometrics, 126(1), 25-51, http://doi.org/10.1016/j. jeconom.2004.02.005. 